\title{
FGF21 wt Allele
}

National Cancer Institute

\section{Source}

National Cancer Institute. FGF21 wt Allele. NCI Thesaurus. Code C51426.

Human FGF21 wild-type allele is located within 19q13.1-qter and is approximately $3 \mathrm{~kb}$ in leng th. This allele, which encodes fibroblast growth factor 21 protein, plays a role in several biological processes, including cell survival. 